\title{
HEAD AND NECK MALIGNANCY IN YOUNG FEMALES - OUR EXPERIENCE
}

Ruma Guha ${ }^{1}$, Satadal Mondal ${ }^{2}$, Jayanta Saha ${ }^{3}$, Kaustav Das Biswass ${ }^{4}$ Ramanuj Sinha ${ }^{5}$

\section{HOW TO CITE THIS ARTICLE:}

Ruma Guha, Satadal Mondal, Jayanta Saha, Kaustav Das Biswas, Ramanuj Sinha. "Head and Neck Malignancy in Young Females - Our Experience". Journal of Evolution of Medical and Dental Sciences 2014; Vol. 3, Issue 03, January 20; Page: 707-713, DOI: 10.14260/jemds/2014/1890

ABSTRACT: Head and neck cancer is more common in males and is a disease of older age group. Yet it may occur in young female patients, a rare and different group of patients. India has the world's highest incidence of head and neck neoplasms in women. Here we share our experience of head and neck malignancy in young females forming baseline data and stimulating further study on possible ways of prevention.

KEYWORDS: Head-neck carcinoma, young female patients, SCC (Squamous Cell Carcinoma)

INTRODUCTION: Head and neck cancer is the fifth most common cancer worldwide and is the most common neoplasm in central Asia. ${ }^{1}$ Male to female ratio of head and neck malignancy varies between 2: 1 to 4: 1.2 In India head and neck cancer is accounting for $23 \%$ of total cancer incidence among male and $6 \%$ among female. ${ }^{2}$ Even though the world's highest reported incidence of head and neck neoplasm in women is in India ${ }^{3}$, majority of head neck cancer are squamous cell carcinoma (SCC). Among the non-SCC histology there are adenocarcinoma, adenoid cystic carcinoma from major or minor salivary gland, Kaposi Sarcoma, and other histological entities.

In a study by Funk et $\mathrm{al}^{4}$ approximately $48 \%$ of oral cavity cancers in patients younger than 35 years were SCC, versus $88 \%$ in patients $36-65$ years and $91 \%$ of patients older than 65 years. Tobacco and alcohol are the major risk factor for head and cancer, but different studies have found a variable and sometimes absent relationship with these traditional risk factors in young patients and in female 5-8. These traditional risk factors are also less important in cases of non-SCC of the head and neck.

MATERIALS AND METHODS: Patients were selected from the Otorhinolaryngology clinic of our institution within the period of two years (July 2009 to June 2011). All the cases of head and neck malignancy (proved by histopathology) were included in the study except thyroid malignancy as the latter has a clear predilection for the young female patients. After obtaining the detailed history, routine clinical evaluation and routine laboratory investigations, the patients were subjected to CT scan of the relevant area and tissue biopsy from the tumor. Table-1 shows the distribution of cases according to the involved site and histopathological diagnosis. Table- 2 shows the individual details of the cases. 


\begin{tabular}{|l|l|c|}
\hline \multicolumn{1}{|c|}{$\begin{array}{c}\text { Site of malignancy } \\
\text { (according to site) }\end{array}$} & \multicolumn{1}{|c|}{ Histopathological type } & Number of cases \\
\hline Sinonasal malignancy & $\begin{array}{l}\text { Squamous Cell Carcinoma } \\
\text { (poorly differentiated / undifferentiated) }\end{array}$ & 2 \\
\hline Nasopharyngeal Malignancy & $\begin{array}{l}\text { Non-Keratinizing } \\
\text { Undifferentiated Carcinoma }\end{array}$ & 1 \\
\hline Laryngeal malignancy & Squamous Cell Carcinoma & 1 \\
\hline \multirow{2}{*}{ Temporo-mastoid region malignancy } & $\begin{array}{l}\text { Squamous Cell Carcinoma } \\
\text { (poorly differentiated) }\end{array}$ & 1 \\
\cline { 2 - 3 } & Adenoid cystic carcinoma & 1 \\
\hline Base of the tongue malignancy & Adenoid cystic carcinoma & 1 \\
\hline
\end{tabular}

\begin{tabular}{|c|c|c|c|c|c|c|c|}
\hline $\begin{array}{c}\text { Case } \\
\text { No. }\end{array}$ & $\begin{array}{l}\text { Age } \\
\text { in } \\
\text { yrs. }\end{array}$ & $\begin{array}{c}\text { Addic } \\
\text { tion }\end{array}$ & Site & $\begin{array}{c}\text { Pre-operative } \\
\text { Biopsy }\end{array}$ & Treatment Done & $\begin{array}{l}\text { Histopathology } \\
\text { report }\end{array}$ & $\begin{array}{l}\text { Follow up } \\
\text { result }\end{array}$ \\
\hline 1. & 22 & None & $\begin{array}{l}\text { Left Sinonasal } \\
\text { region (Fig. 1) }\end{array}$ & $\begin{array}{l}\text { Poorly } \\
\text { differentiated } \\
\text { carcinoma }\end{array}$ & $\begin{array}{l}\text { Neo adjuvant } \\
\text { chemotherapy + } \\
\text { Medial Maxillectomy } \\
\text { + post-operative } \\
\text { radiotherapy }\end{array}$ & $\begin{array}{l}\text { Poorly } \\
\text { differentiated } \\
\text { carcinoma }\end{array}$ & $\begin{array}{l}\text { No } \\
\text { recurrence } \\
\text { in } 18 \\
\text { months. }\end{array}$ \\
\hline 2. & 21 & None & $\begin{array}{l}\text { Right Sinonasal } \\
\text { region (Fig. 2) }\end{array}$ & $\begin{array}{l}\text { Inflammatory } \\
\text { polyp }\end{array}$ & $\begin{array}{l}\text { Removal of mass via } \\
\text { lateral Rhinotomy } \\
\text { approach } \\
\text { (chemotherapy and } \\
\text { radiotherapy given } \\
\text { post -operatively) }\end{array}$ & $\begin{array}{l}\text { Non-keratinizing } \\
\text { undifferentiated } \\
\text { carcinoma }\end{array}$ & $\begin{array}{l}\text { Died after } 1 \\
\text { year due to } \\
\text { ovarian } \\
\text { metastasis. }\end{array}$ \\
\hline 3. & 31 & None & $\begin{array}{l}\text { Right vocal cord } \\
\text { (Fig 3) }\end{array}$ & $\begin{array}{l}\text { Moderately } \\
\text { differentiated } \\
\text { squamous cell } \\
\text { carcinoma }\end{array}$ & $\begin{array}{l}\text { Concurrent } \\
\text { Chemotherapy and } \\
\text { Radiotherapy }\end{array}$ & $\mathrm{X}$ & $\begin{array}{l}\text { No } \\
\text { recurrence } \\
\text { in } 2 \text { years }\end{array}$ \\
\hline 4. & 35 & None & $\begin{array}{l}\text { Base of the } \\
\text { tongue } \\
\text { (Fig 4) }\end{array}$ & $\begin{array}{l}\text { Adenoid cystic } \\
\text { carcinoma }\end{array}$ & $\begin{array}{l}\text { Excision of the mass } \\
\text { with mandibulotomy }\end{array}$ & $\begin{array}{l}\text { Adenoid cystic } \\
\text { carcinoma }\end{array}$ & $\begin{array}{l}\text { No } \\
\text { recurrence } \\
\text { in } 6 \text { months }\end{array}$ \\
\hline 5. & 32 & None & $\begin{array}{l}\text { Right } \\
\text { temporomastoid } \\
\text { region (Fig } 5 \& 6 \text { ) }\end{array}$ & $\begin{array}{l}\text { Poorly } \\
\text { differentiated } \\
\text { Squamous cell } \\
\text { carcinoma }\end{array}$ & $\begin{array}{l}\text { Wide excision with } \\
\text { post-operative } \\
\text { concurrent } \\
\text { chemoradiation }\end{array}$ & $\begin{array}{l}\text { Poorly } \\
\text { differentiated } \\
\text { squamous cell } \\
\text { carcinoma }\end{array}$ & $\begin{array}{l}\text { Lost to } \\
\text { follow up } \\
\text { after } 3 \\
\text { months }\end{array}$ \\
\hline 6 & 22 & $\begin{array}{c}\text { Betel } \\
\text { nut }\end{array}$ & $\begin{array}{l}\text { Nasopharynx } \\
\text { (Fig 7) }\end{array}$ & $\begin{array}{l}\text { Non-keratinising } \\
\text { undifferentiated } \\
\text { carcinoma }\end{array}$ & $\begin{array}{l}\text { No surgical } \\
\text { Intervention }\end{array}$ & Chemoradiation & $\begin{array}{l}\text { Patient lost } \\
\text { to follow up } \\
\text { after two } \\
\text { months }\end{array}$ \\
\hline 7. & 19 & None & $\begin{array}{l}\text { Right external } \\
\text { auditory canal } \\
\text { (Figure 8) }\end{array}$ & $\begin{array}{l}\text { Adenoid cystic } \\
\text { carcinoma }\end{array}$ & Wide excision & $\begin{array}{l}\text { Adenoid cystic } \\
\text { carcinoma }\end{array}$ & $\begin{array}{l}\text { No } \\
\text { recurrence } \\
\text { in } 2 \text { years }\end{array}$ \\
\hline
\end{tabular}


RESULT: During the study period total 72 patients were diagnosed to have malignancy in the head and neck region. 19 of them were female (M: $\mathrm{F}=2.8: 1)$. Seven of them were female aged 35 or less (36.84\% of the female patients); no patient had any form of addiction except the case of Nasopharyngeal carcinoma had the addiction of betel nut. In one case pre-operative biopsy was not a malignant one but post-operative histopathology revealed undifferentiated carcinoma. Only surgical treatment was given to one patient, concurrent chemoradiotherapy was given to the case of laryngeal carcinoma \& Nasopharyngeal carcinoma and other three patients was treated with combined surgery and post-operative radiation+/- chemotherapy (neoadjuvant/post-operative concurrent). One of the patients lost from the follow up and one patient died subsequently due to distant metastasis. Other four patients remain free from recurrence till date. In all our cases there was no any family history of malignancy.

DISCUSSION: Head and neck neoplasia (HNN) is a major form of cancer in India. Tobacco and alcohol play an important role in the aetio-pathogenesis of HNN, therefore majority are preventable. ${ }^{9}$ The higher prevalence of HNN in relation to other malignancies in India may be due to the use of tobacco for smoking and chewing, consumption of alcohol and low socioeconomic condition leading to poor hygiene, poor diet or infections of viral origin. ${ }^{10}$

In Indian subcontinent the incidence rate of head and neck neoplasm among male exceeds $30 / 1,00,000$ and in female exceeds 10/1, 00, $000{ }^{9}$. Tobacco and alcohol are related to mainly the squamous cell carcinoma of head and neck region. But in our study, 2 out of 7 patients were having non-squamous cell malignancy. Head and neck squamous cell carcinoma (HNSCC) typically develops in the sixth to seventh decade of life ${ }^{11}$ But incidence of head and neck carcinoma in the lower age group is rising.

Funk proposed the following 3 groupings of young patients with head and neck cancer 4

- Group I is composed of young women (< 35 years) with few to no risk factors and aggressive squamous cell carcinoma (SCC)

- Group II are typically young males (<40 years) with heavy risk factors and disease typical of older patients

- Group III has a slight male predominance but fewer risk factors and relatively welldifferentiated disease.

Out of the seven patients in the present study four cases fall into the group I of the Funk classification. ${ }^{4}$ These patients have no known risk factors for developing head and carcinoma. Other two patients having non-squamous cell carcinoma which are not related to the risk factors like smoking or alcohol. Therefore none of our cases were preventable by primary prevention methods. Early diagnosis and treatment was the only modality of intervention to save the life of these patients. To achieve the goal of early diagnosis high degree of suspicion is required in the group of patients described in the present study, where neither the age or sex are matched with the most cases of head and neck malignancy nor having any known risk factors for development of the disease.

Study from Denmark by Olsen JH failed to get any relationship of cigarette smoking in development of sinonasal malignancy whereas occupational exposure has some role to play ${ }^{12}$ although our cases were free from any occupational exposure to carcinogens. In the study on UK population performed by Oliver RJ et al oral cancer in young population is found to be uncommon leading to delayed diagnosis or even misdiagnosis culminating in poorer prognosis. ${ }^{13}$ In our study the 
base of tongue adenoid cystic carcinoma case presented with a asymptomatic mucosa covered swelling for short duration of six months causing only dysphagia lately as the mass increased in size \& on FNAC and imaging carcinoma was suspected following which definitive treatment could be provided.

It has also been reported that young patients with oral carcinoma may have genetic predisposition like alteration of tumor suppressor gene p53 leading to increased chance of carcinogenesis by smoking ${ }^{14}$. Shvero J et al reviewed long term data between 1950 \& 1992, reporting 96 women with SCC larynx, of whom 59\% had glottic carcinoma, mostly (72\%) in stage I. Smoking, although a risk factor is less important than in males ${ }^{15}$. The case in our study is also free from any history of addiction. DeRienzo DP et al found an increase in incidence of laryngeal carcinoma in women from 0.5 to 1.5 per 100, 000 population over the period from 1947 to 1984, with a decline of male-to-female-ratio from 5.6:1 to 4.5:1 over the period 1959 to 1988 which further substantiates greater incidence among women ${ }^{16}$ In another study by Shvero J et al, advanced SCC of larynx was noted in high percentage in patients younger than 40 years, the survival rate is same or better than their older counterparts. This supports aggressive treatment of primary, recurrence and second primary, which is better tolerated in younger patients who are free from usual co-morbidities yielding better prognosis ${ }^{17}$.

Following the same principle the glottic SCC case of our study was treated with concomitant chemoradiation with curative intent $\&$ the patient is free from recurrence in 2 year follow-up. Glottic SCC was found to be most common followed by supraglottic SCC in patients younger than 30 years and has been related to malignant degeneration of papillomas, complication of radiotherapy for papillomas and infection with human immunodeficiency virus by Rutt AL et al ${ }^{18}$ Abe $\mathrm{T}$ et al ${ }^{19}$ described a middle aged woman having adenoid cystic carcinoma (ACC) originating from external auditory canal with intracranial extension.

In our study temporo-mastoid region involvement by ACC as well as SCC was noted, one case each but patients were younger than the normal peak age of occurrence of the carcinomas especially for SCC, the peak prevalence of which is in the 50-59 years age group as found in the study by Mehrotra $\mathrm{R}$ et $\mathrm{al}^{9}$ has been postulated that some patients are genetically predisposed to development of carcinomas at an exceptionally young age \& efforts are underway to identify these predisposed individuals by genetic analysis in order to facilitate primary prevention. As a result of such an effort, Pfeiffer J et al reported strings of consecutive homozygous SNPs (single-nucleotide polymorphism) that were longer than usual indicating regions of DNA deletions named as germline LOH (loss of heterozygosity) which predisposes younger \& non-tobacco users to development of HNSCC.20 But widespread use of such expensive DNA analysis is still not possible in resource poor country like India.

CONCLUSION: The fact reasserted from our study is head \& neck carcinomas can occur in young female patients who may not have exposure to known carcinogens and may suffer from genetic predisposition to carcinogenesis. So probability of carcinomatous involvement should always be ruled out in cases of non-healing ulcers or proliferative masses in head neck region not accountable otherwise. Only a high index of suspicion can only provide the benefit of early diagnosis \& curative treatment to this group of atypical patients. Genetic analyses predicting increased chance of carcinogenesis are being investigated \& new horizons are approaching throwing new lights on 
molecular biology of carcinogenesis, yet they are still of limited utility in day-to-day clinical practice in view of high patient load as well as logistical constraint in our country. Thorough clinical examination supplemented by proper investigation as well as collection \& comparison of data through nationwide cancer registry system can go a long way in benefit of these unfortunate patients improving their quality of life.

\section{REFERENCES:}

1. Parkin DM, Pisani P, Ferlay J. Global cancer statistics. CA Cancer J Clin. 1999; 49:33.

2. National Cancer Registry Programme-Biennial Report (1988-89) of the National Cancer Registry Programme. New Delhi: Indian Council of Medical Research, Surya Printers. 1992; 342.

3. Sankaranarayanan R, Masuyer E, Swaminathan R, Ferlay J, Whelan S. Head and neck cancer: a global perspective on epidemiology and prognosis. Anticancer Res. 1998;18:4779-86

4. Funk GF, Karnell LH, Robinson RA, Zhen WK, Trask DK, Hoffman HT. Presentation, treatment, and outcome of oral cavity cancer: a National Cancer Data Base report. Head Neck. Feb 2002; 24(2):165-80.

5. Schantz SP, Byers RM, Goepfert H, Shallenberger RC, Beddingfield N. The implication of tobacco use in the young adult with head and neck cancer. Cancer. Oct 1 1988; 62(7):1374-80.

6. Martin-Granizo R, Rodriguez-Campo F, Naval L, Diaz Gonzalez FJ. Squamous cell carcinoma of the oral cavity in patients younger than 40 years. Otolaryngol Head Neck Surg. Sep 1997; 117(3 Pt 1):268-75.

7. Pytynia KB, Grant JR, Etzel CJ, Roberts D, Wei Q, Sturgis EM. Matched analysis of survival in patients with squamous cell carcinoma of the head and neck diagnosed before and after 40 years of age. Arch Otolaryngol Head Neck Surg. Jul 2004; 130(7):869-73.

8. Siegelmann-Danieli N, Hanlon A, Ridge JA, Padmore R, Fein DA, Langer CJ. Oral tongue cancer in patients less than 45 years old: institutional experience and comparison with older patients. J Clin Oncol. Feb 1998; 16(2):745-53.

9. Mehrotra R, Singh M, Gupta RK, Singh M, Kapoor AK. Trends of prevalence and pathological spectrum of head and neck cancers in North India. Indian J Cancer. 2005; 42:89-93.

10. Mehrotra R, Singh M, Kumar D, Pandey AN, Gupta RK, Sinha US. Age specific incidence rate and pathological spectrum of oral cancer in Allahabad. Indian J Med Sci. 2003; 57:400-4.

11. Byers RM. Squamous cell carcinoma of the oral tongue in patients less than thirty years of age. Am J Surg. Oct 1975; 130(4):475-8.

12. Olsen JH. Epidemiology of sinonasal cancer in Denmark, 1943-1982. Acta Pathologica Microbiologica Scandinavica Series A. 1987; Pathology; 95A: 171-175.

13. Oliver RJ, Dearing J, Hindle I. Oral cancer in young adults: report of three cases and review of the literature. Br Dental J. 2000; 188:362-366.

14. Raybaud-Diogène H, Tétu B, Morency R, Fortin A, Monteil R A. p53 overexpression in head \& neck SCC: review of the literature. Oral Oncology. 1996; 32: 143-149.

15. Shvero J, Hader T, Feinmesser R, Har-El G, Martin D, Marshak G, Segal K. Laryngeal carcinoma in females. Eur J Surg Oncol. 1996 Feb; 22(1):61-4. 
16. DeRienzo DP, Greenberg SD, Fraire AE. Carcinoma of the larynx. Changing incidence in women. Arch Otolaryngol Head Neck Surg. 1991 Jun; 117(6): 681-84.

17. Shvero J, Hadar T, Segal K, Abraham A, Sidi J. Laryngeal carcinoma in patients 40 years of age and younger. Cancer. 1987 Dec 15; 60(12):3092-5.

18. Rutt AL, Hawkshaw MJ, Sataloff RT. Laryngeal cancer in patients younger than 30 years: a review of 99 cases. Ear Nose Throat J. 2010 Apr; 89(4): 189-92.

19. Abe T, Kondo A, Suga M, Sunami N, Yamamoto Y. Adenoid cystic carcinoma with striking intracranial extension: a case report. (Article in Japanese) No Shinkei Geka. 2004; 32(8): 85156.

20. Pfeiffer J, Wiech T, Maier W, Ridder GJ, Laszig R, Birkenhäger R. Head and neck cancer in young adults and non-smokers: Study of cancer susceptibility by genome- wide high-density SNP microarray mapping. Acta Otolaryngol. 2011 Oct; 131 (10): 1091-8.

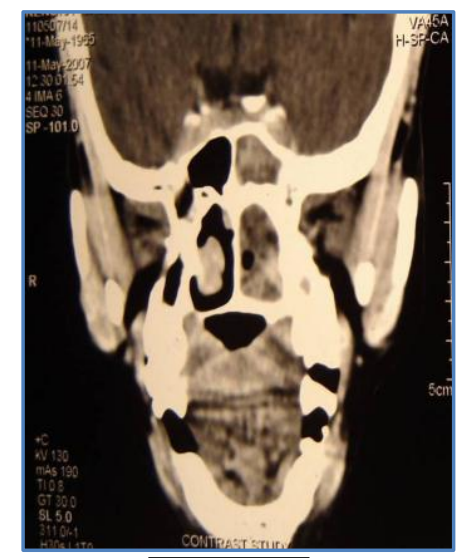

Fig. 1

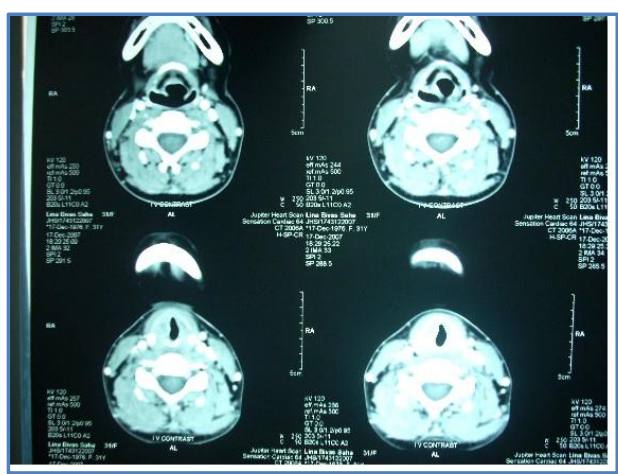

Fig. 3
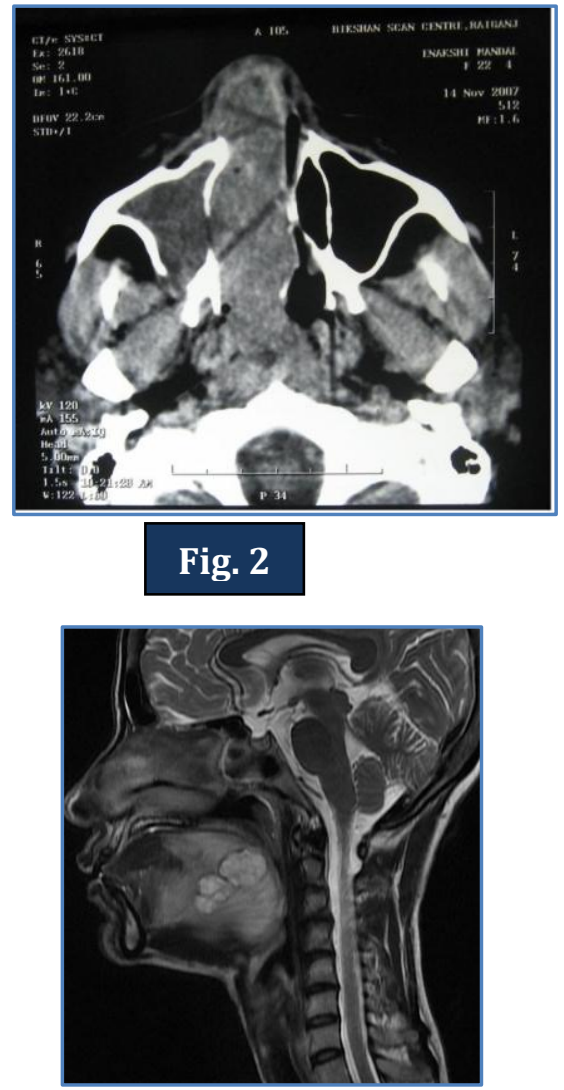

Fig. 4 


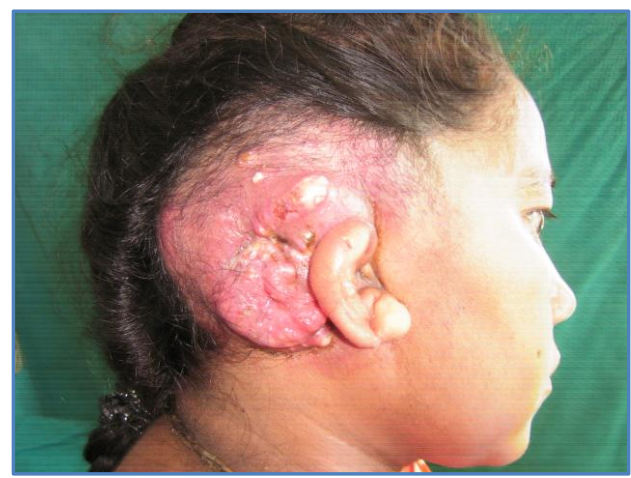

Fig. 5

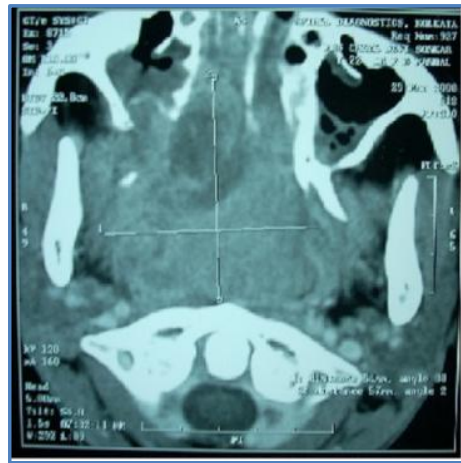

Fig. 7

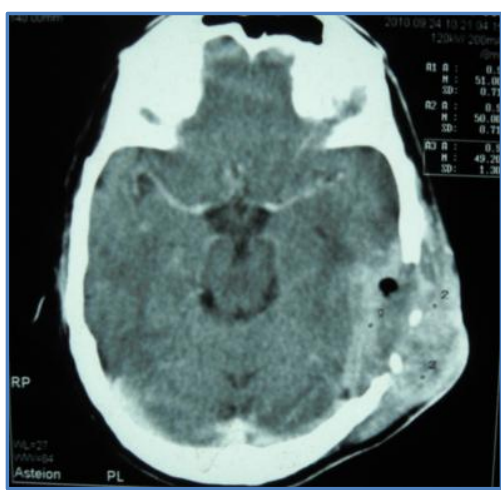

Fig. 6

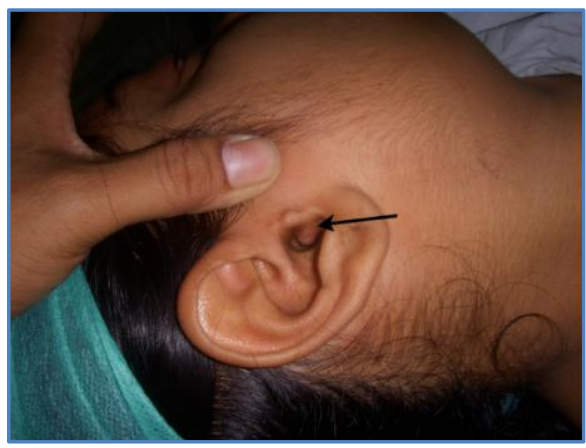

Fig. 8

\section{AUTHORS:}

1. Ruma Guha

2. Satadal Mondal

3. Jayanta Saha

4. Kaustav Das Biswas

5. Ramanuj Sinha

\section{PARTICULARS OF CONTRIBUTORS:}

1. RMO cum Clinical Tutor, Department of ENT, R.G. Kar Medical College \& Hospital, Kolkata, West Bengal.

2. Assistant Professor, Department of ENT, R.G. Kar Medical College \& Hospital, Kolkata, West Bengal.

3. Assistant Professor, Department of ENT, R.G. Kar Medical College \& Hospital, Kolkata, West Bengal.
4. Senior Resident, Department of ENT, R.G. Kar Medical College \& Hospital, Kolkata, West Bengal.

5. Professor, Department of ENT, R.G. Kar Medical College \& Hospital, Kolkata, West Bengal.

\section{NAME ADDRESS EMAIL ID OF THE CORRESPONDING AUTHOR:}

Dr. Ruma Guha,

"Maya Vila", Plot. 108; Sec: A;

Metropolitan Co-Operative Housing Society Ltd., Kolkata - 700105 .

Email - rumaent@rediffmail.com

Date of Submission: 30/12/2013.

Date of Peer Review: 31/12/2013.

Date of Acceptance: 07/01/2014.

Date of Publishing: 17/01/2014. 